\begin{tabular}{l|c|l}
\hline \hline Biological and & Vol. 5(2): 248-259, 2021 & $\begin{array}{l}\text { ISSN: 2002-6153 } \\
\text { Biol. Appl. Environ. Res. } \\
\text { www.baerj.com } \\
\text { editor@a baerj.com }\end{array}$ \\
\hline
\end{tabular}

\title{
Description of Six Species of Myxobolus Bütschli, 1882 (Myxozoa: Myxosporea) from Freshwater Fish Species in Iraq
}

\author{
Kefah N. Abdul-Ameer ${ }^{1 *} \&$ Jabbar A. Abbas ${ }^{2}$ \\ ${ }^{1}$ Department of Biology, College of Education for Pure Science, \\ University of Baghdad, Baghdad, Iraq \\ ${ }^{2}$ Al-Rusafa III Education Directorate, Baghdad, Iraq \\ *Corresponding author: kefahnaser59@yahoo.com
}

\begin{abstract}
Two hundred and fifty-five fishes, belonging to six species, were collected weekly from the Tigris River in the Al-Ataifiya Region, Baghdad City during the period from July 2018 until the end of March 2019. The examination of skin and gills of these fishes showed the occurrence of six Myxobolus species. These included: M. erythrophthalmi, M. fahmii, M. gobiorum, M. ichkeulensis, M. saugati and M. sclerii. The description and measurements, besides the illustrations of these myxozoans parasites are given here for the first time in Iraq. In addition, a list of all Myxobolus species, so far recorded from the six infected fish species is given.
\end{abstract}

Keywords: Myxozoa, Myxobolus spp., Tigris River, Baghdad, Iraq

\section{Introduction}

Myxozoans are microscopic metazoan parasites belonging to the phylum Myxozoa. They infect a variety of hosts and fishes are the most common hosts that reported all around the World (Lom \& Dykova, 2006). The genus Myxobolus Bütschli, 1882 is the largest genus among myxozoans, with 856 nominal species and considered as the most prevalent genus worldwide (Eiras et al., 2005, 2014). Spores of this genus are microscopic, multicellular, and exist as pseudocysts within tissues (histozic) or between tissues (coelozoic). These pseudocysts can exist in various host tissues in a manner of white to pale yellow pock on the affected parts of the body and enable to be seen in naked eyes (Kaur \& Singh, 2008-2009; Gupta \& Kaur, 2017). Myxobolus species infect different organs of freshwater fishes such as skin, fins, gills, eye, heart, gallbladder, liver, kidneys, spleen and wall of the alimentary canal (Kaur, 2014).

In Iraq, the first study about Myxobolus species was by Herzog (1969) on $M$. muelleri Bütschli, 1882, M. multiplicatus (Reuss, 1906) and M. oviformis Thelohan, 1892. Subsequently, several surveys were carried out on fish parasites from different Iraqi inland waters and some fish ponds and farms revealed the record of 98 Myxobolus species (Mhaisen \& Al-Jawda, 2020). Recently, Al-Jawda \& Ali (2021) recorded an additional Myxobolus species: $M$. hemibarbi Dogiel \& 
Akhmerov in Akhmerov, 1960 from the yellow barbell Carasobarbus luteus for the first time in Iraq in addition to the record of 20 fish host records for 12 Myxobolus species in Iraq. So, more studies on fish parasites are needed to record more parasite species and increase our knowledge of the fish's parasitic fauna in Iraq.

The present paper documents the first description of six Myxobolus species from gills of six freshwater fish species from Tigris River in Al-Ataifiya Region, Baghdad City.

\section{Materials and Methods}

Two hundred and fifty-five fishes, belonging to six species (Table 1), were collected weekly from Tigris River in Al-Ataifiya Region, Baghdad City during the period from July 2018 until the end of March 2019. Live fishes were brought to the laboratory. They have been identified based on Coad (2010) and followed Fricke et al. (2021) for updating the valid names. These fishes included five cyprinid fishes (Arabibarbus grypus, Carasobarbus luteus, Garra rufa, Luciobarbus barbulus and L. xanthopterus) in addition to one leucisid fish (Chondrostoma regium). External organs of these fishes (skin, fins, gills and scales) were examined by dissecting microscope to detect plasmodium that had been smashed to obtain spores. Fresh smears from these organs, in addition to, internal organs (eye, gallbladder, liver, spleen, kidneys, heart and wall of the alimentary canal) were taken from fishes and macroscopically examined for spores.

The spores were immediately photographed in a live state by using a digital camera. For permanent specimens, the spores were fixed in absolute methanol for 2-8 minutes and then stained with Giemsa solution for about 25-30 minutes, then washed in water and desiccated (Saha \& Bandyopadhyay, 2017).

Drawings were done by a Camera Lucida. Spores were described and measured according to the guidelines of Lom \& Arthur (1989). All measurements, unless otherwise indicated, are given in micrometer $(\mu \mathrm{m})$ as minimum-maximum (mean) values. Updating the scientific name of fishes was done according to Froese \& Pauly (2021). The information on the previous records of myxozoans of fishes of Iraq was achieved from the index-catalogue of parasites and disease agents of fishes of Iraq (Mhaisen, 2021).

\section{Results and Discussion}

The examination of fishes showed their infection with six Myxobolus species. The distribution of these parasites, their location on the fish host's body, and the prevalence of infection are demonstrated in Table (1). 
Table 1: Distribution of Myxobolus species on their fish hosts.

\begin{tabular}{|l|l|c|c|c|c|}
\hline \multirow{2}{*}{ Myxobolus species } & \multicolumn{1}{|c|}{ Host fish } & \multicolumn{2}{|c|}{ No. of fishes } & Prevalence & $\begin{array}{c}\text { Site of } \\
\text { infection }\end{array}$ \\
\cline { 3 - 4 } & & examined & infected & & (\%) \\
\hline M. erythrophthalmi & C. regium & 37 & 2 & 5.4 & Gills \\
\hline M. fahmii & C. luteus & 50 & 1 & 2 & Gills, Skin \\
\hline M. gobiorum & L. xanthopterus & 48 & 1 & 2.1 & Gills \\
\hline M. ichkeulensis & A. grypus & 84 & 2 & 2.4 & Gills, Skin \\
\hline M. saugati & L. barbulus & 26 & 1 & 3.9 & Gills \\
\hline M. sclerii & G. rufa & 10 & 1 & 10 & Gills \\
\hline
\end{tabular}

The following is the description and measurements of these parasites (in $\mu \mathrm{m}$ ), based on five specimens of each parasite species.

\section{Myxobolus erythrophthalmi Molnár, Eszterbauer, Marton, Cech \& Székely, 2009 (Figure 1)}

This parasite was isolated from gills of C. regium with a prevalence of $5.4 \%$. According to Mhaisen (2021), the only record of this parasite from fishes of Iraq was that from $C$. regium by Abbas (2019). As neither detailed description nor measurements for this parasite were published yet, the following is an account of such information.

The plasmodia were not found during examination of the gill swabs, but several spores were found scattered between the secondary lamellae of gill filaments. The spores are mostly ellipsoid with seven sutural edge markings observed in fresh spores. Spore length 11.0-11.8 (11.4) and width 9.6-8.8 (9.4). Two pyriform polar capsules, equal in size, slightly converging anteriorly and occupying approximately half the length of the spore, length 6.1-6.5 (6.3) and width 3.0-3.8 (3.4). No intercapsular appendix was seen, but a small thickening between capsules could be observed. The sporoplasm is homogenous and occupying whole of the extracapsular space behind the polar capsules. The description and measurements of the present $M$. erythrophthalmi are in agreement with those reported by Molnár et al. (2009) from the blood vessels in the renal interstitium of Scardinius erythrophthalmus in the Lake Balaton, Hungary. 

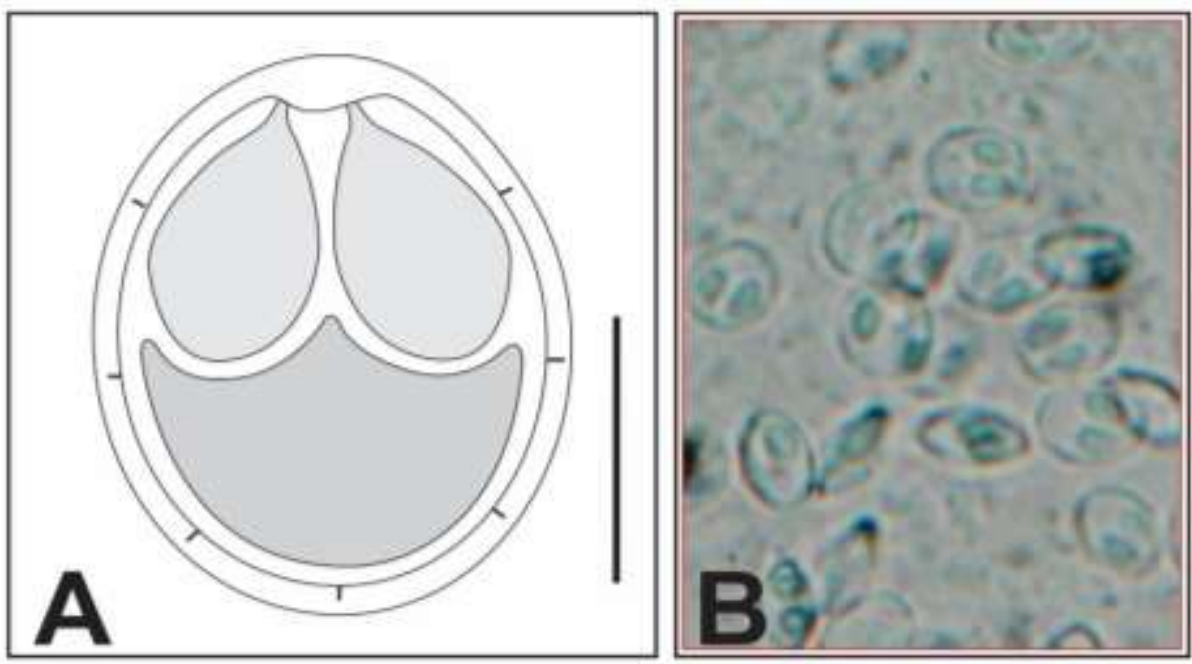

Figure 1: Myxobolus erythrophthalmi. A: Camera Lucida drawing (Scale bar $=6 \mu \mathrm{m})$. B: Photomicrograph (400x).

\section{Myxobolus fahmii Ali, Al-Rasheid, Sakran, Abdel-Baki \& Abdel-Ghaffar, 2002 (Figure 2)}

This parasite was found on skin and gills of $C$. luteus with a prevalence of $2 \%$. The only record of this parasite from fishes of Iraq was that from C. luteus by Abbas (2019). As neither detailed description nor measurements for this parasite were published yet, the following is an account of such description and measurements.

The plasmodia were not found during examination of the gill swabs, but several spores were found scattered in skin smears and between the secondary lamellae of gill filaments. Spores are pear-shaped with a characteristic nipplelike anterior tip. Spore length 11.2-11.8 (11.5) and width 6.8-7.2 (7.0). Two pyriform polar capsules, equal in size, converge from the front at over two-thirds of their length and occupied more than half the spore length and are placed at a distance posteriorly, length 7.2-7.4 (7.3) and width 3.4-3.6 (3.5). No intercapsular appendix was seen. The sporoplasm is homogenous and occupying whole of the extracapsular space behind the polar capsules. The descriptions and measurements of the present $M$. fahmii showed agreement with those described by Ali et al. (2002) from gills of Niger barb Barbus bynni (=Labeobarbus bynni) from the Nile River in Egypt. 

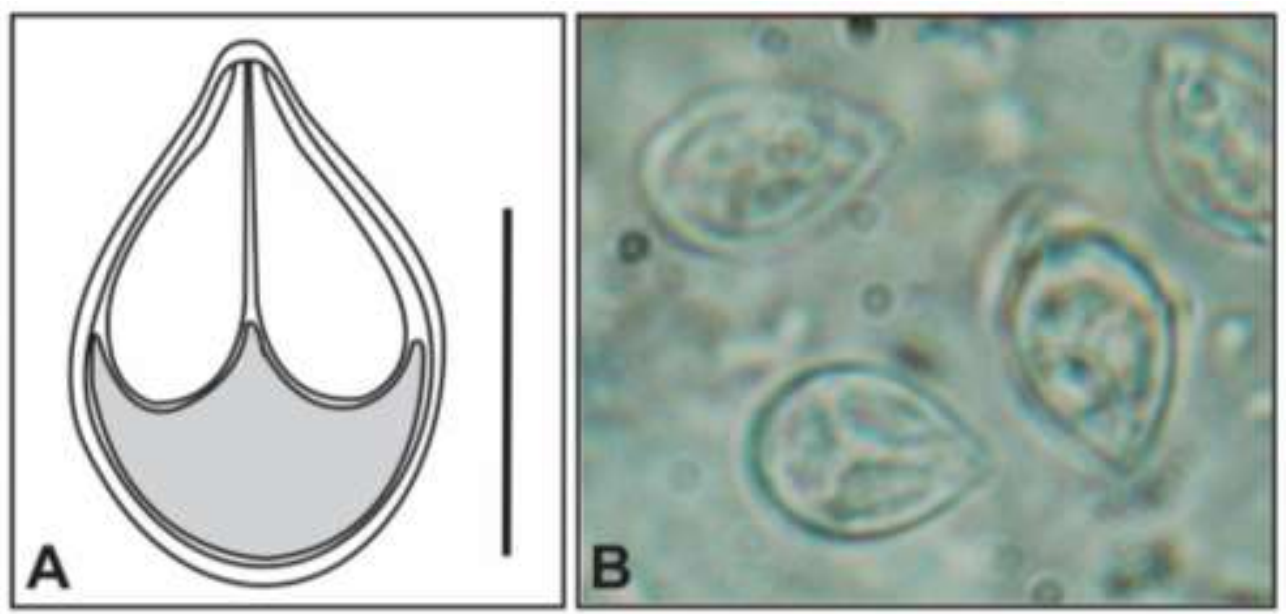

Figure 2: Myxobolus fahmii. A: Camera Lucida drawing (Scale bar $=7.4 \mu \mathrm{m})$.

B: Photomicrograph (400x).

\section{Myxobolus gobiorum Donec, 1984 (Figure 3)}

This parasite was isolated from gills of $L$. xanthopterus with a prevalence of $2.1 \%$. The only record of $M$. gobiorum from fishes of Iraq was from $C$. luteus by Abbas (2019). The following is an account of description and measurements of this parasite as neither detailed description nor measurements for this parasite were published yet.

Plasmodia of this parasite are dark, small and oval to spherical cysts, mostly found between secondary lamellae of gills and measured 0.06-0.12 (0.09) $\mathrm{mm}$ in diameter. Spores are oval, elongated in shape with rounded anterior and posterior ends. Spore length 10.2-11.4 (10.6) and width 8.4-9.2 (8.8). Two pyriform polar capsules, equal in size, far from each other and occupied about half of the spore, length 5.2-5.6 (5.4) and width 2.2-2.6 (2.3). Intercapsular process visible and triangle in shape. The sporoplasm is granular occupying most of the posterior part of the spore behind the polar capsules. M. gobiorum measurements and description in the present study are in agreement with those mentioned by Shul'man (1984) from fins of Gobio gobio in the Kuban ponds and reservoirs of the Crimean peninsula. 


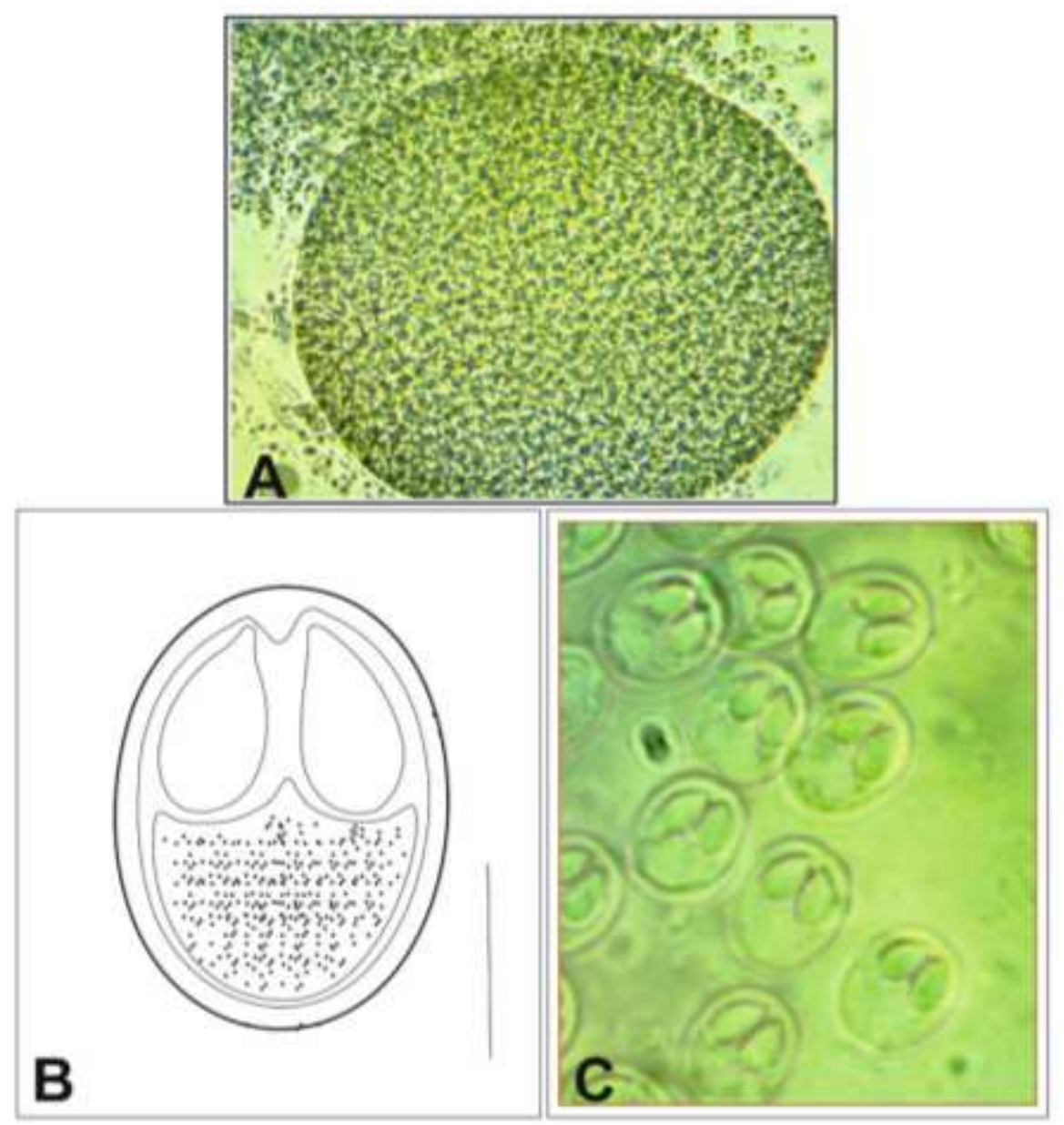

Figure 3: Myxobolus gobiorum. A: Photomicrograph of plasmodium (400x), B: Camera Lucida drawing (Scale bar $=5.2 \mu \mathrm{m})$. C: Photomicrograph $(400 \mathrm{x})$.

\section{Myxobolus ichkeulensis Bahri \& Marques, 1996 (Figure 4)}

This species was obtained from skin and gills of A. grypus with a prevalence of $2.4 \%$. This parasite was recorded for the first time in Iraq from A. grypus by Abbas (2019). As neither detailed description nor measurements for this parasite are published yet, the following is an account of such information.

Plasmodia of this parasite are dark, small and rounded to spherical cysts, mostly found between primary and secondary lamellae of gills and measured 0.08-1.1 $(0.09) \mathrm{mm}$ in diameter. Spores are spherical with nine sutural edge markings. Spore length 13.3-13.9 (13.6) and width 12.2-12.8 (12.5). Two oval polar capsules, equal in size and reach with their posterior end to half the length of the spore, length 5.56.1 (5.8) and width 4.1-4.3 (4.2). No intercapsular was visible between the anterior ends of the polar capsules. The sporoplasm is homogenous and fills half of the spore length. The description and measurements of the present $M$. ichkeulensis are in agreement with those reported by Bahri \& Marques (1996) from gills and fins of Carassius auratus and Mugil cephalus in Lake Ichkeul in northern Tunisia. 

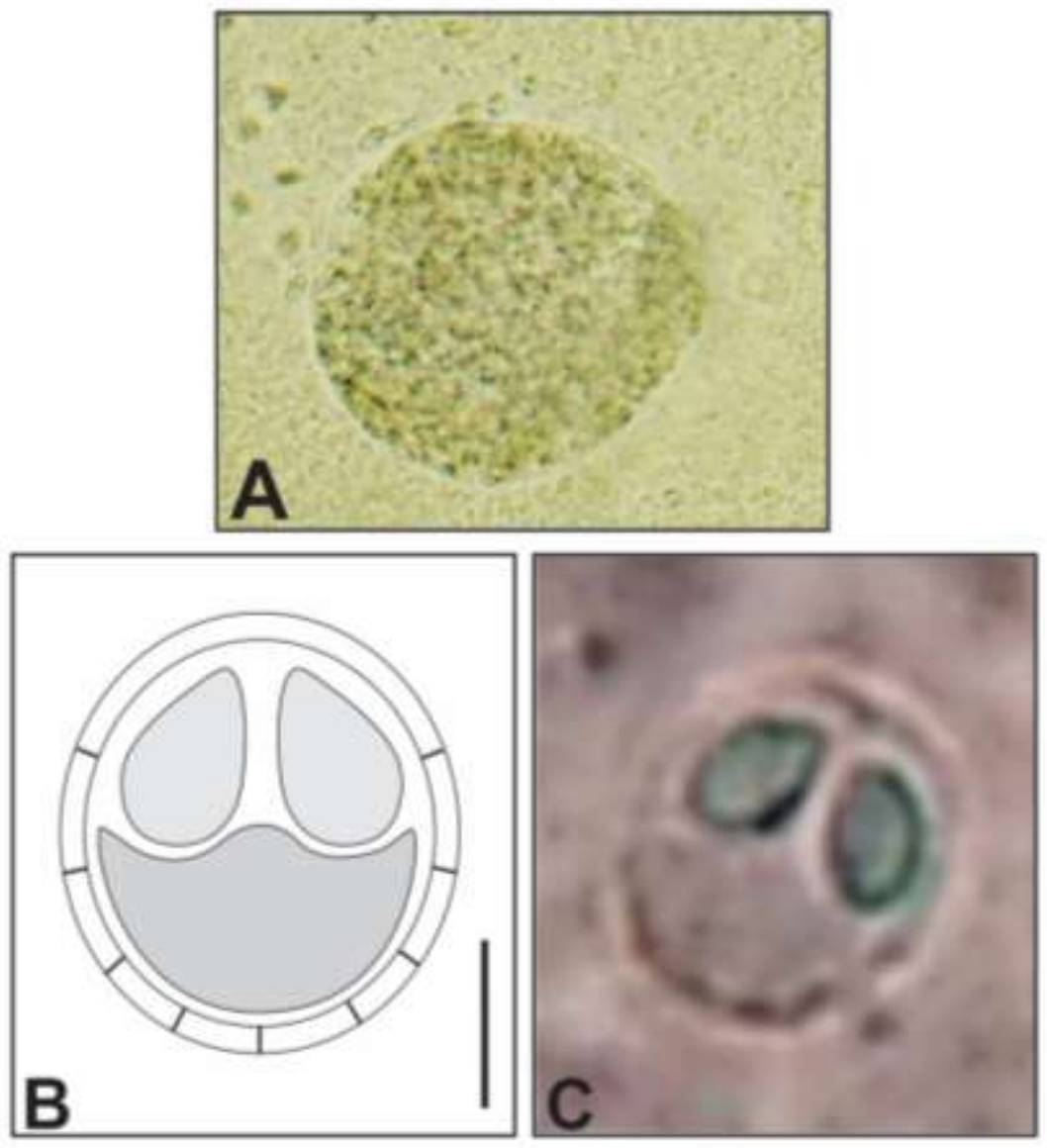

Figure 4: Myxobolus ichkeulensis A: Photomicrograph of plasmodium (400x), B: Camera Lucida drawing (Scale bar $=4.8 \mu \mathrm{m})$. C: Photomicrograph $(400 \mathrm{x})$.

\section{Myxobolus saugati Kaur \& Singh, 2011 (Figure 5)}

This species was recorded from gills of L. barbulus with a prevalence of 3.9\%. M. saugati was firstly recorded in Iraq from L. barbulus by Abbas (2019). The following is an account on description and measurements of this parasite as neither description nor measurements are published yet.

The plasmodium was not found in the swabs taken from the gills, but clusters of spores were found between the secondary gill lamellae. The spores are ovoid with a rounded anterior and posterior ends. Spore length 8.2-8.6 (8.4) and width 6.2-7.0 (6.6). Two pyriform polar capsules with the distinct neck at the anterior end, equal in size, converge anteriorly and are placed at a distance posteriorly and exceeding half length of the spore, length of capsule 4.0-4.4 (4.2) and width 1.2-1.6 (1.4). An intercapsular process is absent. Sporoplasm is granular and occupying whole of the extracapsular space behind the polar capsules. Description and measurements of $M$. saugati in the present study agree with those mentioned by Kaur \& Singh (2011) on Labeo rohita scales in Kanjali River in Punjab, India. 

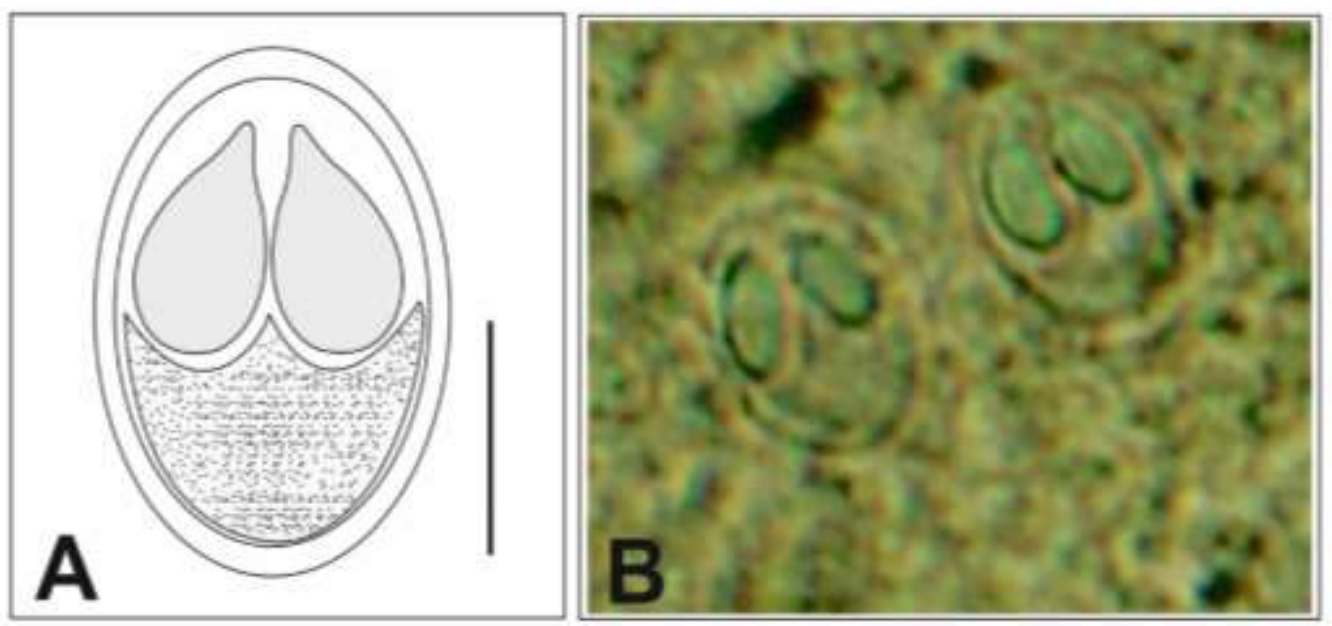

Figure 5: Myxobolus saugati. A: Camera Lucida drawing (Scale bar $=4 \mu \mathrm{m})$.

B: Photomicrograph (400x).

\section{Myxobolus sclerii Kaur \& Singh, 2010 (Figure 6)}

This parasite was isolated from gills of $G$. rufa with a prevalence of $10 \%$.This parasite was recorded for the first time in Iraq from G. rufa by Abbas (2019). As neither detailed description nor measurements for this parasite are published yet, the following is an account of such information.

Plasmodia of this parasite are small, dark, oval to spherical cysts, mostly found between secondary lamellae of gills and measured 0.6-0.8 (0.7) $\mathrm{mm}$ in diameter. Spores are pyriform with a narrow anterior end and broad and rounded posterior end. Spore length 8.3-8.9 (8.6) and width 4.8-5.2 (5.0). Two pyriform polar capsules equal in size, converging closely towards the anterior end but placed at distance posteriorly and occupy more than half of the spore cavity, length 4.1-5.3 (4.7) and width 1.4-1.6 (1.5). A medium-sized, rod-shaped intercapsular process present. Sporoplasm is homogenous and half-moon shaped. The description and measurements of the present $M$. sclerii agree with those of $M$. sclerii from the eyeball of the catla Catla catla $(=$ Gibelion catla) in Kanjali waters in India (Kaur \& Singh, 2010. 


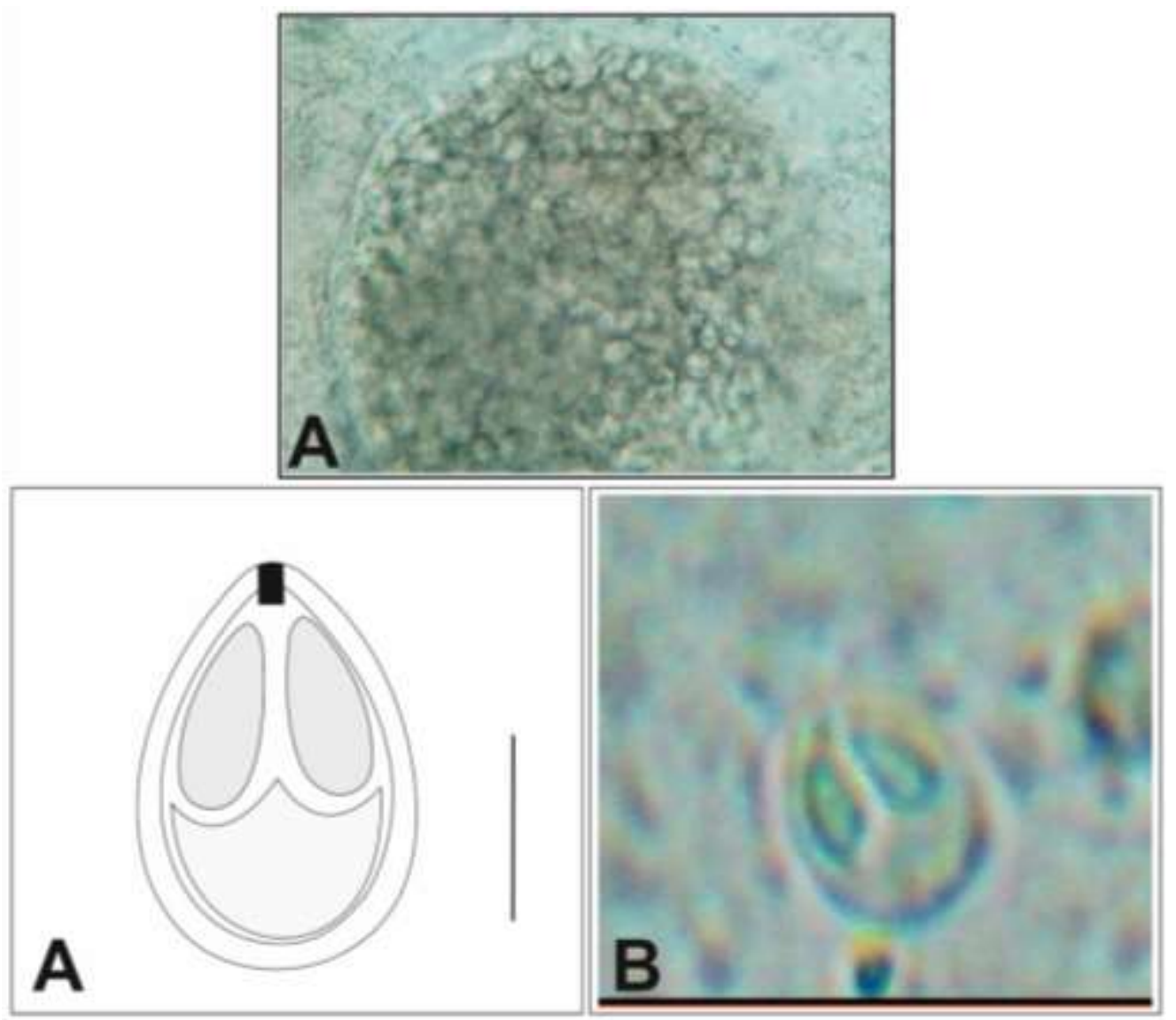

Figure 6: Mxobolus sclerii. A: Photomicrograph of plasmodium (400x), B: Camera Lucida drawing (Scale bar $=4 \mu \mathrm{m})$. C: Photomicrograph $(400 \mathrm{x})$.

Finally, it is worth to mention here all the previously reported Myxobolus species so far recorded from the six infected fishes of the present study, depending on Mhaisen (2021) are as in the following.

A. grypus is infected with 39 species of Myxobolus which included $M$. amurensis, M. bramae, M. branchialis, M. branchiophilus, M. buckei, M. carassii, M. caudatus, M. chondrostomi, M. cyprinicola, M. dispar, M. dogieli, M. drjagini, M. ellipsoides, $M$. exgiuus, $M$. ichkeulensis, $M$. intrachondrealis, $M$. karelicus, $M$. karuni, M. koi, M. krokhini, M. kubanicus, M. lussi, M. macrocapsularis, M. muelleri, M. multiplicatus, M. musculi, M. naffari, M. nemacheili, M. niei, M. orientalis, M. oviformis, M. parvus, M. persicus, M. pfeifferi, M. poljanski, M. problematicus, M. schulmani, M. sphaericus, M. szekeli as well as unidentified Myxobolus species.

C. luteus is infected with 66 species of Myxobolus which included M. acutus, $M$. adeli, M. amurensis, M. bliccae, M. bouixi, M. bramae, M. branchilateralis, $M$. bulbocordis, M. chondrostomi, M. cyprini, M. cyprinicola, M. dermatobius, $M$. dispar, M. dogieli, M. drjagini, M. ellipsoides, M. exgiuus, M. fahmii, M. feisti, M. follius, $M$. gigi, $M$. hemibarbi, $M$. impressus, $M$. intrachondrealis, $M$. iranicus, $M$. 
karuni, M. koi, M. kubanicus, M. lobatus, M. lomi, M. macrocapsularis, M. magnus, M. mesopotamiae, M. muelleri, M. musajevi, M. musculi, M. nemacheili, M. niei, M. obpyriformis, M. orientalis, M. oviformis, M. paludinosus, M. parvus, M. permagnus, M. persicus, M. pethericii, M. pfeifferi, M. phylloides, M. poljanski, $M$. problematicus, $M$. pseudodispar, $M$. pseudorasborae, $M$. rotundatus, $M$. sanagaensis, M. schulmani, M. sessabai, M. shadgani, M. sharpeyi, M. spatulatus, M. sphaericus, M. sprostoni, M. squamae, M. suturalis, M. szekeli, M. talievi and M. uniporus.

C. regium is infected with 23 species of Myxobolus which included M. alienus, M. branchialis, M. bulbocordis, M. cyprinicola, M. dermatobius, M. dispar, M. drjagini, M. erythophthalmi, M. impressus, M. karuni, M. kubanicus, M. muelleri, M. musculi, M. naffari, M. oviformis, M. paludinosus, M. parvus, M. pfeifferi, M. poljanski, M. pseudodispar, M. schulmani, M. sharpeyi and M. sphaericus.

G. rufa is infected with M. dogieli, M. drjagini, M. musculi, M. oviformis and M. sclerii.

L. barbulus is infected with 13 Myxobolus species which included M. chuatsi, M. cyprinicola, M. dispar, M. drjagini, M. kubanicus, M. lussi, M. macrocapsularis, M. muelleri, M. oviformis, M. pfeifferi, M. saugati, M. shadgani and M. sphaerocapsularis.

L. xanthopterus is infected with 25 Myxobolus species which included $M$. acutus, M. bramae, M. cyprinicola, M. dispar, M. dogieli, M. drjagini, M. ellipsoides, M. gobiorum, M. improvisus, M. koi, M. kubanicus, M. molnari, M. muelleri, M. nemacheili, M. oviformis, M. parvus, M. pfeifferi, M. poljanski, M. rotundus, $M$. sandrae, $M$. sphaericus, $M$. sphaerocapsularis, M. squamae, M. tilapiae, M. yini as well as unidentified Myxobolus species.

\section{Acknowledgement}

Thanks are due to Prof. Dr. Furhan T. Mhaisen for providing necessary information concerning the records of Myxobolus species from his index-catalogue of parasites and disease agents of fishes of Iraq (Mhaisen, 2021).

\section{References}

Abbas, J.A. (2019). The parasitic fauna of some species of fishes from Tigris River at Al-Autaifia Region, Baghdad Province, Iraq. M. Sc. Thesis, Coll. Educ. Pure Sci. Ibn Al-Haitham, Univ. Baghdad: 140 pp. (In Arabic).

Ali, M.A.; Al-Rasheid, K.A.S.; Sakran, T.; Abdel-Baki, A.-A. \& Abdel-Ghaffar, F.A. (2002). Some species of the genus Myxobolus (Myxozoa: Myxosporea) infecting freshwater fish of the River Nile, Egypt, and the impact on their hosts. Parasitol. Res., 88(1): 9-15. DOI:10.1007/s004360100449.

Al-Jawda, J.M. \& Ali, M.H. (2021). Myxosporeans (phylum Myxozoa) parasitic on some fishes from Hamrin Lake in Diyala Province, Iraq. Biol. Appl. Environ. Res., 5(1): 141-151. DOI:10.51304/ baer.2021.5.1.141.

Bahri, S. \& Marques, A. (1996). Myxosporean parasites of the genus Myxobolus from Mugil cephalus in Ichkeul lagoon, Tunisia: Description of two new 
species. Dis. Aquat. Org., 27: 115-122.

Coad, B.W. (2010). Freshwater fishes of Iraq. Pensoft Publ, Sofia: 274 pp. +16 pls.

Eiras, J.C.; Molnár, K. \& Lu, Y.S. (2005). Synopsis of the species of Myxobolus Butschli, 1882 (Myxozoa: Myxosporea: Myxobolidae). Syst. Parasitol., 61(1): 1- 46. DOI:10.1007/s11230-004-6343-9.

Eiras, J.C.; Zhang, J. \& Molnár, K. (2014). Synopsis of the species of Myxobolus Butschli, 1882 (Myxozoa: Myxosporea, Mtxobolidae) described between 2005 and 2013. Syst. Parasitol., 88(1): 11-36. DOI:10.1007/s11230-0149484-5.

Froese, R. \& Pauly, D. (eds.) (2021). FishBase. World Wide Web electronic publication. www.fishbase.org, version (02/ 2021).

Gupta, A. \& Kaur, H. (2017). Morphological and molecular characterization of Myxobolus puntiusii n. sp. (Cnidaria: Myxosporea) infecting Puntius sophore Hamilton, 1822 from Ranjit Sagar wetland, Punjab (India). Turk. J. Zool., 41: 791-799. DOI:10.3906/zoo-1606-47. DOI:10.3906/zoo-1606-47.

Herzog, P.H. (1969). Untersuchungen über die parasiten der süßwasserfische des Irak. Arch. Fischereiwiss., 20(2/3): 132-147.

Kaur, H. (2014). Myxozoan infestation in freshwater fishes in wetlands and aquaculture in Punjab (India). Adv. Anim. Vet. Sci., 2(9): 488-502. DOI: 10.14737/journal.aavs/2014/2.9.488.502.

Kaur, H. \& Singh, R. (2008-2009). Incidence of myxozoan parasites in freshwater fishes of Punjab wetlands. J. Punjab Acad. Sci., 5-6(1 \& 2): 88-91.

Kaur, H. \& Singh, R. (2010). A new myxosporean species Myxobolus sclerii sp. nov. and one known species M. stomum Ali et al. 2003 from two Indian major carp fishes. J. Parasit. Dis., 34(1): 33-39. DOI:10.1007/s12639-010-0010-7.

Kaur, H. \& Singh, R. (2011). Two new species of Myxobolus (Myxozoa: Myxosporea: Bivalvulida) from freshwater fishes of Punjab wetlands (India). J. Parasit. Dis., 35(1): 33-41. DOI:10.1007/s12639-011-0024-9.

Lom, J. \& Arthur, J.R. (1989). A guideline for the preparation of species description in Myxosporea. J. Fish Dis., 12(2): 151-156. DOI:10.1111/j.13652761.1989.tb00287.x.

Lom, J. \& Dyková, I. (2006). Myxozoan genera: Definition and notes on taxonomy, life-cycle terminology and pathogenic species. Fol. Parasitol., 53(1): 1-36.

Mhaisen, F.T. (2021). Index-catalogue of parasites and disease agents of fishes of Iraq. (Unpublished: mhaisenft@yahoo.co.uk).

Mhaisen, F.T. \& Al-Jawda, J.M. (2020). Checklists of the species of Myxobolus Bütschli, 1882 (Cnidaria: Myxozoa: Myxobolidae) from fishes of Iraq. Biol. Appl. Environ. Res., 4(2): 127-166.

Molnár, K.; Eszterbauer, E.; Marton, Sz.; Cech, G. \& Székely, Cz. (2009). Myxobolus erythrophthalmi sp. n. and Myxobolus shaharomae sp. n. (Myxozoa: Myxobolidae) from the internal organs of rudd, Scardinius erythrophthalmus (L.), and bleak, Alburnus alburnus (L.). J. Fish Dis., 32(3): 219-231. 
Saha, M. \& Bandyopadhyay, P.K. (2017). Parasitological and histological analysis of a new species of the genus Thalohanellus and description of a myxozoan parasite (Myxosporea: Bivalvulida) from cultured ornamental goldfish, Carassius auratus L. Aquac. Rep., 8: 8-15. DOI:10.1016/j.aqrep.2017.07. 001.

Shul'man, S.S. (1984) Parasitic Protozoa. In: Bauer, O.N. (Ed.) Key to determination of the parasites of freshwater fish of the USSR, Leningrad. 